\title{
Holiday effects in the South African futures market
}

\author{
C.F. Smit \& E.vd M. Smit \\ Graduate School of Business, University of Stellenbosch, P.O. Box 610, Bellville, 7535 Republic of South Africa
}

Received July 1998

\begin{abstract}
International and local research in share markets offered evidence of a holiday effect. Pre-holiday mean returns are significantly higher than on other trading days. The holiday effect cannot be separated from the weekend effect, as holidays which fall on Fridays and Mondays also influence the weekend analysis. Both these effects exist in their own right. Research on international futures markets supports the existence of a holiday effect. The present study investigates the holiday effect on daily returns of the All Gold Near Futures contract, the All Industrial Near Futures contract and the All Share Near Futures contract in the South African futures market. A distinction is made between pre-holidays, post-holidays and non-holidays. None of the near futures contracts exhibit a significant holiday effect, although signs of a holiday effect are present. It is further shown that the month-end effect is not strongly influenced by the holiday effect. It is also concluded that the pre-holiday effects are not large enough to be exploited on an on-going basis in the South African futures market.
\end{abstract}

\section{Introduction}

Since the turn of the century various studies have focussed on determining seasonal anomalies in financial markets. The main focus had been on share markets and long-term bond markets. Most of the research was initiated in the United States and further research followed in other international markets. Empirical evidence has been provided by various researchers in support of seasonal anomalies, such as the day-of-the-week, weekend, turn-of-the-month and turn-of-the-year effects.

The holiday effect is defined as a seasonal anomaly that may exist in the daily returns on trading days before and/or after holidays. Non-holidays are defined as all trading days, excluding the pre-holidays and post-holidays. The holiday effect was identified as early as 1931 by Fields (Thaler, 1987: 170), but was not particularly well researched until the late 1960s. Research results have shown support for a holiday effect as an anomaly in its own right. The post-holiday mean returns are higher after weekends, when mean returns are usually lower. French (Thaler, 1987: 171) therefore concluded that the holiday effect is not merely a closed-market effect. Ariel (1990: 1621) concluded that the pre-holiday effect is not a manifestation of other calendar anomalies, such as a weekend effect or a January effect.

The search for seasonal anomalies in the international futures markets started in the early 1980s, with limited daily trading data available. The pre-holiday returns in the futures markets have shown higher mean returns than for other trading days, similar to the higher pre-holiday mean returns on the share markets. The close-to-close cumulative returns of pre-holidays contribute to a high proportion of the overall market return, much higher than the proportion of pre-holidays to non-holidays in the sampling periods.

The purpose of this study is to determine whether the holiday effect also exists in the South African futures market. The statistical significance of the holiday effect will be investigated for three South Airrican futures contracts namely: All Gold Near Futures (ALGNF); All Industrial Near Futures (ALINF) and All Share Near Futures (AL-
SNF). The research results of the South African futures market holiday effect are compared with the holiday effects on the South African share market, as well as with the research findings on international share and futures markets.

The second section covers important contributions in the literature on seasonal anomalies in chronological order, focussing on the holiday effect. The third section covers the data description and method of analysis. The different holidays are discussed, as well as the handling of problem data. The empirical results are discussed in the fourth section and the research results are summarised in the fifth.

\section{Review of related research}

\section{Share markets}

Fields (Thaler, 1987: 170) was the first to study the weekend effect on the security markets. He investigated the conventional Wall Street wisdom at the time that

'the unwillingness of traders to carry their holdings over the uncertainties of a week-end leads to a liquidation of long accounts and a consequent decline of security prices on Saturday'.

He actually found that the Saturday prices tend to rise for the Dow Jones Industrial Average (DJIA). In a later study (1934) Fields also found a high proportion of positive returns on the trading days on the DJIA before long weekends (Thaler, 1987: 170).

The above average returns before holidays have been noted by various share market advisers. These advisers in clude Merril who analysed the DJIA for the period 1897 to 1965, and Fosback who later (1976) studied the S\&P 500 Index returns (Ariel, 1990: 1611). These two studies led the way to active research on the holiday effect.

Cross (Thaler, 1987: 171) studied the S\&P 500 Index during 1973, and found that the mean return for Mondays was $-0.18 \%$ and on Fridays $0.12 \%$. French (Thaler. 1987: 171) following up on this research during 1980 , obtained similar results. He found negative mean returns on Mondays, but with the other days showing positive mean returns. The highest returns were on Wednesdays and 
Fridays. French (Thaler, 1987: 171) suggested that the negative mean return on Mondays could be attributed to some unknown 'closed-market effect'. If this were true, one can expect daily returns to be lower after weekends, as well as after holidays. However, the mean returns are higher than normal after holidays, excluding Tuesdays. Tuesdays show a negative mean return following a Monday holiday.

Detailed studies by Roll (Ariel, 1990: 1611) in 1983 found high returns accruing to small firms on the trading day prior to New Year's Day'. Studies by Lakonishok \& Smidt (Ariel, 1990: 1611) in 1984 showed that daily closing prices also rise on trading days before Christmas. These studies highlight the importance of the holiday period at the turn of the year.

Rogalski (1984) analysed the effects of Mondays, weekends and holidays on the DJIA. The Friday to Monday close-to-close returns are on average positive for January, but on average negative for the rest of the year when holidays and holiday-weekends were excluded from the analysis. The mean returns were determined separately for the trading days after holidays and after weekends which include holidays. He reported that the mean returns on weekends which include holidays from Thursday close to Monday close are similar in sign and magnitude to returns from Friday close to Monday close. There is also no obvious relationship with firm size. The Friday to Tuesday holiday weekends differ from the above and are to a certain extent related to firm size. The two-day calendar holiday returns from Wednesday to Friday are greater for small firms. The mean return for Fridays, after Thursday holidays, is relatively larger in magnitude.

Lakonishok \& Smidt (Thaler, 1987: 173) found that $51 \%$ of the capital gains of the past 90 years occurred on the preholidays, highlighting the size of the pre-holiday returns. Their research on the DJIA shows a mean return for preholidays of $0.219 \%$, in contrast with the mean return of $0.0094 \%$ for other days. This gives a ratio of $23: 1$ for preholiday to other trading days returns.

Ariel (1990: 1614) researched the holiday effect on an equally weighted index of shares and a value weighted index of shares of the Centre for Research in Security Prices (CRSP) for the period 1963 to 1982. The pre-holiday mean returns are $0.528 \%$ and $0.364 \%$ for the indices respectively, compared to the non-holiday mean returns of $0.059 \%$ and $0.026 \%$ respectively. This pre-holiday to other day ratio of mean returns is 8.9 for the equally weighted index, while the ratio for the value weighted index is 14.0. The differences between the mean returns are statistically significant. The post-test period results from 1983 to 1986 also support the high mean returns for pre-holidays, and therefore supports the presence of a holiday effect. His research shows that pre-holidays represent only $3.19 \%$ of the 251 average trading days in a year, while $34.7 \%$ of the 20 year cumulative return has been earned on these pre-holidays. The preholidays with positive returns vary between $75 \%$ to $85.6 \%$ of total pre-holidays, as compared to the $53.8 \%$ to $55.8 \%$ of positive returns among the other trading days. These higher ratios of positive pre-holiday returns are significantly different from the rest of the trading days. Ariel (1990: 1614) found that the pre-holiday variance of returns is actually lower than the variance of returns for all other trading days, and concludes that 'this fact serves to emphasise that the pre-holiday return is not a reward for bearing extra risk'. Ariel (1990: 1621) also concluded that 'pre-holiday returns are not a manifestation of other calendar anomalies', for example the January effect or the weekend effect. The high mean return on pre-New Year's Day is not driven by the strong January effect.

Pettengill \& Jordan (1988) showed that pre-holiday returns are uniformly higher than on other trading days, regardless of the day of the week. Wednesdays have shown the highest pre-holiday mean return, with the lowest preholiday mean return on a Monday. The Monday pre-holiday mean return, however, is still four times higher than mean returns on other trading days.

Holidays and weekends are both considered a form of market closing. Lakonishok \& Smidt (Fabozzi, Ma \& Briley, 1994: 307) noted that the pre-holiday returns are two to five times higher than pre-weekend returns. They therefore suggest that another factor, other than the closed-market factor, is present. Coursey \& Dyl (Thaler, 1987: 175) suggested that the weekend effect might be explained by psychological factors. It is also suggested that 'other behavioural explanations might incorporate variations in the mood of the market participants'. This will be more applicable to good moods before holidays and weekends and the bad moods on Mondays. These findings are supported by Deldin, Levin \& Irwin (Fabozzi et al., 1994: 308).

Pettengill (1989) has shown that the return on pre-holidays varies by holiday, day of the week on which the holiday falls, and firm size. He made use of the S\&P 500 Index for the large firm portfolio. The mean return for post-holidays is less than the mean return for non-holidays of large firms, but not for small firms. The mean returns for days before and after holidays are significantly different from non-holidays, but only the mean returns for pre-holidays are significantly higher. The study has shown consistency of holiday returns over years.

A study by Kim \& Park (1994) confirmed the high preholiday returns in the three major United States share markets and demonstrated that the holiday effect is also present in the United Kingdom and Japan share markets, even though the holidays and institutional arrangements differ from country to country. Various empirical studies provide evidence of international linkages of share market returns. Kim \& Park (1994) used the Financial Times 30 Index (FT 30 ) of the UK, the Nikkei-Dow Index of Japan and the S\&P 500 Index of the USA in their analysis. Their study has shown the holiday effect in the share markets of the different countries to be independent.

Kim \& Park (1994) concluded that the Japanese holiday effect is not a closed-market effect. They further concluded that

'institutional factors such as trading methods, clearing mechanisms, settlement procedures, and bid-ask spreads cannot be possible explanations for international evidence of the holiday effect, because these institutional factors are different across countries'. 


\section{Futures markets}

The trading in share index futures only began in 1982 (Khaksari \& Bubnys, 1992: 534), therefore most studies in areas of futures price anomalies use small sample sizes. Research done in 1983 by Chiang \& Tapley (Johnston, Kracaw \& McConnell, 1991: 24) found a Monday effect and weekly seasonal effects in daily returns on a variety of futures contracts. The Dyl \& Maberly research (Johnston $e t$ al., 1991) of 1986 found that the S\&P 500 Share Index futures shows a closed-market weekend effect.

Cornell (1985) found support for the findings of Rogalski (1984) regarding the S\&P 500 Index, namely a Monday effect, but found no similar patterns for the S\&P 500 Futures for the period May 1982 to July 1984. He concluded that the behaviour of futures prices is consistent with the efficient market hypothesis.

Johnston et al. (1991:25) studied the day-of-the-week effect in American GNMA, T-Bond, T-Note and T-Bill futures contracts. The negative Monday returns are associated with the weekend effect, as with share market returns, and not with holidays and other market closings. They found significant mean returns for Tuesdays after 1984, except for the T-Bill contracts. They excluded returns over holidays in the above-mentioned studies.

A study by Jordan \& Jordan (1991) has shown significant turn-of-the-month and day-of-the-week effects, but no January or turn-of-the-year effects in the S\&P 500 futures contract. Returns tend to be low on Mondays and high on Wednesdays and Fridays. Their results are not qualitatively different after omitting days following holidays.

A recent study (Fabozzi et al., 1994) analysed holiday trading in futures markets for 16 different contracts. The mean pre-holiday return is 12 times higher than the nonholiday mean return for copper futures, and 170 times higher for Treasury Bill contracts. However, most of the pre-holiday mean returns do not significantly differ from the non-holiday mean returns. They further found six of the 16 futures contracts with higher post-holiday mean returns.

Fabozzi et al. (1994: 315) reported significantly lower trading volumes on the pre-holiday trading days for the 16 contracts investigated. Evidence exists that traders appear to avoid trading in periods prior to holidays. It is important to note that trading volume increases when the contract approaches its maturity date, making it more difficult to interpret holiday patterns. They also suggest that the lower volume and higher return pre-holiday trading are

inconsistent with a theory of buying because of a positive holiday psychology. The evidence reported here is more consistent with the prediction of the inventory adjustment hypothesis'.

Fabozzi et al. (1994: 309) included weekday and weekend holidays in the sample to test for the calendar time hypothesis, which suggests that returns vary with the day of the week. The calendar time and trading time hypotheses are both rejected, because of too low pre-holiday returns during the mid-week and too high returns on Monday and Friday.

Chang, Jain \& Locke (1995) analysed the volatility and price changes of the S\&P 500 Index futures around the NYSE close. The volatility in the futures market drops sig- nificantly when the NYSE closes, only to increase again at the close of the futures market. The futures market hid prices therefore follow a U-shaped pattern. They have found the Friday close in the futures market to be the period with the highest volatility, higher than the rest of the week. Their evidence suggests that the size of the marketclosing effect on volatility increases with the anticipated length of time over which the market is closed' (Chang et al., 1995: 61). They concluded that during the final minutes on the Friday, futures markets anticipate the weekend effect as found in equities.

\section{South African research}

Bhana (1985) studied the Monday effect on the JSE, and suggested that neither the calendar time nor the trading time hypothesis can explain the distribution of returns over the trading days of the week. The mean return had been negative for Mondays and positive for the rest of the other days. The highest return has been on Wednesdays. Bhana excluded returns for periods that included holidays. The difference in share returns on the different trading days indicates evidence of a market inefficiency. According to Davidson \& Meyer (1993: 83) the Monday effect is no longer evident on the JSE.

The study of an equally weighted mining share index, industrial share index and an all share index showed an insignificant January effect (Bradfield, 1990). A significant July effect showed up in the mining shares, and a December effect was found in all three indices. Bradfield's (1990: 9) conclusive argument is that the significant seasonal effect in Decernber is more likely to be a result of relatively less volatility than substantial return in December'.

Hattingh \& Smit (1993) examined the seasonal patterns in the daily price movements of the Eskom 168, Post Office and RSA bonds, comparing them with the return patterns of the All Gold Index (AGI), All Industrial Index (AII) and All Share Index (ALSI) on the JSE. Their findings are in contrast to international research findings, namely that seasonal similarities exist between the hond and share markets. No holiday effects had been considered.

The seasonal patterns in the South African market were also investigated by Watson \& Smit (1994: 155). The seasonal patterns of the AGI, the AII and the ALSI on the JSE were analysed and compared with the corresponding near futures contracts on the futures market. The results showed that seasonal similarities exist between the South African futures market and the spot market. The seasonal phenomena were analysed over different sampling periods, but remained stable. This research did not specifically consider any holiday effects. Watson \& Smit (1994: 155) showed that the highest daily returns were from Tuesday to Thursday. The lowest daily returns were on Fridays and Mondays. All three indices show a significant day-ot-the-week effect. Only the All Share Near Futures shows a significant turn-of-the-month effect.

Bhana (1994) evaluated the effect of public holidays on the returns of the companies listed on the JSE for the period 1975 to 1990. The pre-holiday mean returns were five times the mean returns accruing on trading days, excluding pre-holidays. The difference in the mean returns were 
statistically significant. The data for the sampling period was sub-divided into two equal sub-sets, and no variation of the holiday effect was found over time. These results support research by Pettengill (1989), namely that there is no variation in the holiday effect over time.

The variances for pre-holidays are lower than for the other days, emphasising that the high pre-holiday return is no reward for extra risk (Bhana, 1994: 47). He further states that the holiday effect is intimately tied to the weekend effect'. Bhana's results support the closed-market hypothesis, where the days immediately before and after public holidays show a similar pattern to the weekend effect.

Nash (1994: 88) extended the study period of Bhana and included the AGI, the AII and the ALSI on the JSE. He demonstrated a consistently high return on all three indices on a Wednesday. This midweek effect has not been documented in international research. The daily returns were adjusted for the settlement period, after which the negative Monday effect disappeared. The AGI and ALSI displayed no significant day-of-the-week effect.

\section{Summary}

It is evident from research that a holiday effect exists in the international share markets and the futures markets. The holiday effect is also evident in the South African share market. The research methods used, however, were not uniform, making it difficult to directly compare research results.

Various sources indicate support for a weekend effect on the share markets, namely higher mean returns for a Friday and lower mean returns for a Monday. Similar results have been found for the futures markets. It is also concluded that the days affected by Monday and Friday holidays cannot be seen in isolation from the weekend anomaly.

The existence of a holiday effect is supported by the following statistically significant results:

a. The positive mean return for the pre-holidays is higher than the mean return for the non-holidays.

b. There is a higher proportion of positive returns for preholidays than for non-holidays.

c. The cumulative returns over the different sampling periads tend to be much higher for the pre-holidays than for the non-holidays, taking into account that pre-holidays are less than $4 \%$ of the total trading days on the market.

Researchers have found the difference in the mean returns for the different days of the week to be significant.

The theoretical views that may explain the holiday effect are summarised as follows:

a. The holiday effect is due to the favourable holiday psychology on the last trading day before the holiday.

b. It is consistent with the prediction of the inventory adjustment hypothesis.

c. Volatility increases at market closing due to the extended period that the market will be closed.

\section{Description of data and method}

The raw data used in this research study was obtained from the Graduate School of Business of the University of Stellenbosch and from INET. Three futures data series were analysed, namely the ALGNF, the ALINF and the ALSNF. The raw data sample period runs from 5 January

Table 1 Official South African public holidays

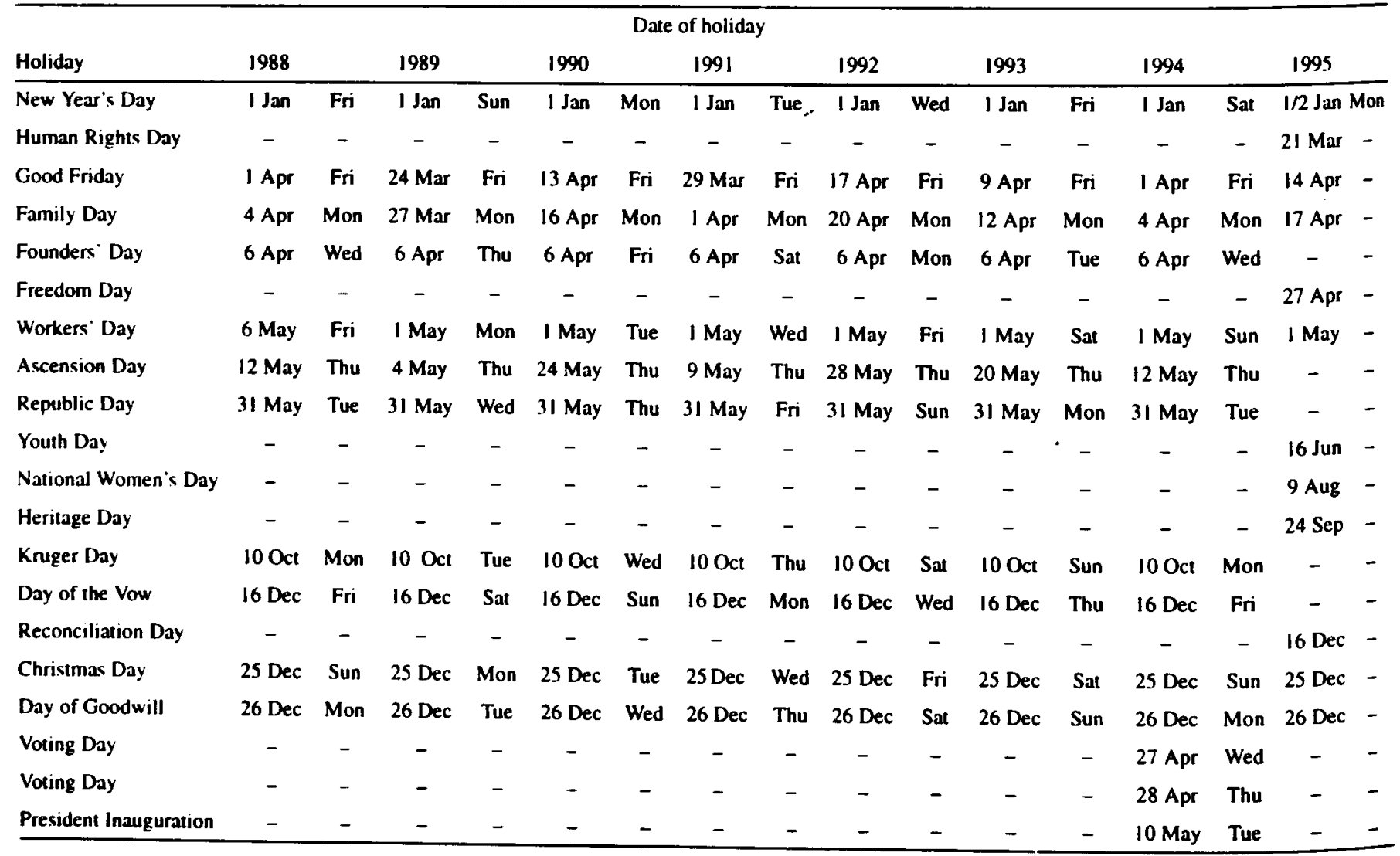


1988 to 10 March 1995. The data consist of the daily closing prices of the near futures contracts.

The daily return is defined as the difference between the closing price on a particular trading day, and the closing price on the previous trading day, as a proportion of the closing price of the previous trading day.

The daily return is therefore modelled as:

$$
R_{1}=\left(P_{1}-P_{1.1}\right) / P_{1-1}
$$

with

$\mathrm{R}_{1}$ as the incremental return for day $t$;

$P_{1}$ as the closing price of the index on day $t$, and

$P_{1-1}$ as the closing price of the index on the previous day, day $t-l$.

The pre-holiday return is defined as the incremental return, or difference, for the two trading days prior to the holiday. The post-holiday return is the difference between the trading day prior to the holiday and the trading day immediately after the holiday. The non-holiday return is the difference between two trading days, excluding the preholiday and post-holiday returns.

Eleven annual South African public holidays were involved in this study. See Table 1 for more details on the South African holidays. Seven of the eleven holidays occur during the first six months of the year. For purposes of future research note that the number of public holidays changed to twelve as from I January 1995. The new holidays are also included in Table 1 . If any future holiday falls on a Sunday, the Monday will be a public holiday. A concentration of five holidays is now found in the period from 21 March to 1 May.

Both Good Friday and Ascension Day are holidays that cause a closing of the market. Other holidays may fall on weekends and will not affect the normal operation of the market. Weekend holidays are treated as follows:

a. The Fridays and Mondays before and after weekend holidays are treated as pre-holidays and post-holidays. This is to ensure that no bias is built into the definition of the trading day prior to and following a public holiday.

b. The alternative approach is to consider only public holidays that can provoke a closing of the market. This approach will only be used in a few comparisons.

It is necessary to deal with the day-of-the-week and other important seasonal effects when testing for the holiday effect. The holiday effect is estimated using the following equation which is derived from the model of Fabozzi et al. (1994: 319).

$$
\begin{aligned}
R_{1}= & \alpha_{1}+\beta_{1} . \text { TUE }+\beta_{2} . \text { WED }+\beta_{3} . \text { THU }+\beta_{4} . \text { FRI }+ \\
& \beta_{5} . \text { JAN }+\beta_{h} . \text { PRE }+\beta_{7} . \text { POST }+\beta_{x} \cdot M D 1+e_{1}
\end{aligned}
$$

with:

$\mathrm{R}_{1}$ as the excess return for contract at time $t$;

$\alpha_{1}$ as a constant that measures the mean return of Mondays;

$\beta_{1}$ to $\beta_{k}$ estimates of the coefficients of the dumny variables, mcasuring the incremental returns;

and the dummy variables as:
TUE to FRI All the non-Monday weekdays of the week ( 1 for daily return on the specific day and 0 for daily returns on the other days);

JAN All the trading days in January are included ( 1 for daily return in January and 0 for daily returns of other months);

PRE The pre-holiday is the last trading day prior to a holiday ( 1 for daily return on the pre-holiday and 0 for daily returns on the other days);

POST The post-holiday is the first trading day following a holiday ( 1 for daily return on the post-holiday and 0 for daily returns on the other days);

MD1 The turn-of-the-month, or month-end, includes the last trading day of the previous month and the first four trading days of the month. This is in line with Fosback (Ariel, 1987: 168) who found that stocks have a marked tendency to rise during the first four days of every month and on the last day of every month, also referred to as the month-end effect.

The multiple dummy variables separate the holiday effect from the day-of-the-week effects. The holiday effect estimators, namely $\beta_{h}$ for a pre-holiday and $\beta_{7}$ for a post-holiday, are therefore independent from the day-of-the-week effects. The regression model further tests whether the returns on Mondays are equal to the returns of the other weekdays. If the weekday returns are equal, the $F$-statistics for the first four dummy variables should be insignificant and the $\beta$ estimates should all be close to zero.

Data for specific dates for all three near futures contracts are incomplete. The incomplete data, as listed in Table 2, is classified as follows:

A Data could not be found at Ivor Jones or SAFEX, and also no explanation for its absence. These few days are ignored and the previous available closing prices are used.

B Some of the missing data can be attributed to the closing of the market on the day hetore or after a holiday, for example on a Monday when the Tuesday is a holiday. These days are regarded as part of the closed-market holiday period.

C The market was closed after a weekend which includes a holiday, therefore this day is regarded as part of the closed-market holiday period.

D Holidays that fall on weekends do not necessitate extra closed-market days. There are ten such weekends with holidays in the sampling period. To test consistently for the holiday effect, the Friday is regarded as a pre-holiday and the Monday as a post-holiday.

The alternative is to regard the weekends with holidays as normal weekends. This aspect will also be tested, to ensure no significant changes take place.

Only the closing prices of the different futures contracts are available. As the opening values of the contracts are not available on the days following a closed-market period, it is not possible to determine whether any profit or loss is experienced in the non-trading period or during the active trading periods. 


\begin{tabular}{|c|c|c|c|c|}
\hline Date & $\begin{array}{c}\text { Missing } \\
\text { data }\end{array}$ & $\begin{array}{c}\text { Possible } \\
\text { closed-market }\end{array}$ & $\begin{array}{c}\text { New Year } \\
\text { extra closing }\end{array}$ & $\begin{array}{l}\text { Weekend } \\
\text { holiday }\end{array}$ \\
\hline & A & B & C & D \\
\hline $29-2-88$ & Mon & & & \\
\hline $5-4-88$ & & Tue & & \\
\hline $27-6-88$ & Mon & & & \\
\hline $2-1.89$ & & & Mon & \\
\hline $17-3-89$ & Fri & & & \\
\hline $5-5.89$ & & Fri & & \\
\hline $9-10-89$ & & Mon & & \\
\hline $6-12-89$ & & & & Sat \\
\hline 6-9-90 & Thu & & & \\
\hline $16-12-90$ & & & & Sun \\
\hline $24-12-90$ & & Mon & & \\
\hline $31-12-90$ & & Mon & & \\
\hline 6-4-91 & & & & Sat \\
\hline $27-12-91$ & & Fri & & \\
\hline $31-5-92$ & & & & Sun \\
\hline $10-10-92$ & & & & Sat \\
\hline $1-5.93$ & & & & Sat \\
\hline $10-10-93$ & & & & Sun \\
\hline $25-12-93$ & & & & Sat \\
\hline $26-12-93$ & & & & Sun \\
\hline 1.1 .94 & & & & Sat \\
\hline $1-5-94$ & & & & Sun \\
\hline
\end{tabular}

\section{Results}

\section{Analysis of holidays}

A distribution of South African holidays, as per day-of-theweek, are listed in Table 3 . Altogether $40 \%$ of the holidays in the research data are concentrated on Mondays and Fridays. The weekend holidays add another $18.8 \%$ of holidays. It therefore emphasises the importance of the days immediately before and after a weekend, as the possibility of a holiday effect may be strongly influenced by a weekend effect.

The holidays are not evenly distributed throughout the week. The number of pre-holidays and post-holidays differ from the actual number of holidays, due to the closing of the market for longer periods and where such a period includes more than one holiday. Four of the trading days are regarded as both pre-holiday and post-holiday, according to the definition of pre-holidays and post-holidays. The focus will actually be on the pre-holidays.

Four of the public holidays fall within the first half of the month, namely on New Year's Day, Founders Day, Workers Day and Kruger Day. Republic Day, Day of the Vow, Christmas Day and Day of Goodwill fall in the latter half of the month. These holidays may fall on weekends as well. The other holidays do not occur consistently in the same half of the month.

Post-holiday returns for Mondays and Tuesdays reflect holidays on Fridays to Mondays, which include weekends or longer periods of market closing. The post-holiday re-
Table 3 South African public holidays for the period 5 January 1988 to 10 March 1995

\begin{tabular}{lcccccccc}
\hline \multicolumn{7}{c}{ Days of the week } \\
Day & Mon & Tue & Wed & Thu & Fri & Sat & Sun & Total \\
\hline New Year's Day & 2 & 1 & 1 & - & 1 & 1 & 1 & 7 \\
Good Friday & - & - & - & - & 7 & - & - & 7 \\
Farnily Day & 7 & - & - & - & - & - & - & 7 \\
Founders' Day & 1 & 1 & 2 & 1 & 1 & 1 & - & 7 \\
Workers' Day & 1 & 1 & 1 & - & 2 & 1 & 1 & 7 \\
Ascension Day & - & - & - & 7 & - & - & - & 7 \\
Republic Day & 1 & 2 & 1 & 1 & 1 & - & 1 & 7 \\
Kruger Day & 2 & 1 & 1 & 1 & - & 1 & 1 & 7 \\
Day of the Vow & 1 & - & 1 & 1 & 2 & 1 & 1 & 7 \\
Christmas Day & 1 & 1 & 1 & - & 1 & 1 & 2 & 7 \\
Day of Good- & 2 & 1 & 1 & 1 & - & 1 & 1 & 7 \\
will & & & & & & & & \\
Voting Day & - & - & 1 & 1 & - & - & - & 2 \\
Presidential & - & 1 & - & - & - & - & - & 1 \\
Inauguration & & & & & & & & \\
\hline Total & 17 & 9 & 10 & 13 & 16 & 7 & 8 \\
\hline Distribution of & $22.5 \%$ & $11.3 \%$ & $12.5 \%$ & $16.3 \%$ & $18.8 \%$ & $8.8 \%$ & $10.0 \%$ & - \\
holidays & & & & & & & & \\
\hline Pre-holidays & 5 & 8 & 11 & 15 & 25 & - & - & 64 \\
Post-holidays & 20 & 17 & 8 & 8 & 11 & - & - & 64 \\
\hline & & & & & & & \\
\hline
\end{tabular}

turns for Wednesdays to Fridays reflect mainly the one-day holidays, or one-day market closings. The kurtosis and skewness of the ALGNF, ALINF and the ALSNF are summarised in Table 4. The day-of-the-week analysis results are shown in Appendices A, B and C.

In general the ALGNF has a high pre-holiday kurtosis, also for a Wednesday, indicating a very steep distribution with long tails. The Wednesday pre-holiday returns are

\begin{tabular}{lcccc}
\hline $\begin{array}{l}\text { Table } 4 \text { Kurtosis } \\
\text { Contracts }\end{array}$ & and & skewness & of near futures \\
\hline Near futures statistics & All days & Pre-holiday & Post-holiday & Non-holiday \\
\hline ALGNF: & & & & \\
Kurtosis & 2.446 & 13.996 & 0.171 & 1.752 \\
Standardised kurtosis & 21.162 & 22.855 & 0.280 & 14.886 \\
Skewness & 0.312 & 2.509 & 0.458 & 0.197 \\
Standardised skewness & 5.400 & 8.192 & 1.495 & 3.348 \\
\hline ALINF: & & & & \\
Kurtosis & 11.220 & 2.449 & 1.874 & 11.277 \\
Standardised kurtosis & 97.085 & 3.999 & 3.060 & 95.828 \\
Skewness & -0.971 & 0.950 & -0.648 & -1.001 \\
Standardised skewness & -16.811 & 3.102 & -2.115 & -17.011 \\
\hline ALSNF: & & & & \\
Kurtosis & 3.903 & 3.949 & 1.368 & 3.867 \\
Standardised kurtosis & 33.775 & 6.449 & 2.234 & 32.859 \\
Skewness & -0.380 & 1.573 & -0.635 & -0.428 \\
Standardised skewness & -6.584 & 5.138 & -2.075 & -7.266 \\
\hline & & & & \\
\hline & & & &
\end{tabular}


positively skewed. The rest of the days show similar flatter distributions. The ALGNF standardised kurtosis of 21.2 and standardised skewness of 5.4 indicate that the ALGNF daily returns differ significantly from a normal distribution. Both the pre-holiday and non-holiday returns differ significantly from a normal distribution. It is only the post-holiday returns of the ALGNF that do not differ significantly from a normal distribution.

The ALINF daily returns have a higher kurtosis for the non-holiday trading days. The ALINF standardised kurtosis of 97.1 and standardised skewness of -16.8 indicate that the ALINF daily returns differ significantly from a normal distribution. All of the ALINF pre-holiday, post-holiday and non-holiday returns differ significantly from a normal distribution.

It is only the Wednesday pre-holiday and post-holiday ALSNF returns that have a higher kurtosis than the nonholiday returns. The pre-holiday returns are all positively skewed, while the post-holiday returns are all negatively skewed, as are most of the non-holiday returns. The $\mathrm{AL}$ SNF standardised kurtosis of 33.8 and standardised skewness of -6.6 indicate that the ALSNF daily returns differ significantly from a normal distribution. All of the ALSNF pre-holiday, post-holiday and non-holiday returns differ significantly from a normal distribution.

From the results in Table 4 it is therefore concluded that all three sets of near futures prices differ significantly from a normal distribution. The t-tests and F-tests are only meaningful if the data are normally distributed. It is therefore concluded that the t-test and F-test results may not be meaningful. The Mann-Whitney test will be used to determine whether the difference in the mean returns between two variables is significant.

The ALGNF pre-holidays show positive mean returns for all weekdays, except for Fridays which have a slightly negative mean return. The ALGNF pre-holiday mean return of $0.47 \%$ is 40.2 times the mean return of non-holidays, which is $0.012 \%$. Only the Monday post-holidays show a positive mean return, contrary to an expected negative Monday effect. The large negative post-holiday mean return for a Tuesday would, however, correspond with the negative return after a weekend market closing. The non-holiday weekdays have negative mean returns for Mondays and Tuesdays.

The ALGNF median is $0.25 \%$ for pre-holiday returns and $-0.33 \%$ for post-holiday returns, while the median for the non-holiday returns is $0.00 \%$. The difference in the medians is tested with the Mann-Whitney U-test. According to the $\mathrm{H}_{10}$ hypothesis the median returns for the pre-holidays and post-holidays are equal to the median return for nonholidays. The $H_{11}$ hypothesis is not rejected at the $5 \%$ significance level, as indicated by the Mann-Whitney $p$-values of 0.17 and 0.44 . The results are given in Table 5 .

The ALINF pre-holidays show positive mean returns for Tuesdays, Wednesdays and Fridays. The ALINF pre-holiday mean return is 2.9 times the mean return for non-holidays. The Monday and Friday post-holidays show a positive mean return. The non-holiday weekdays have negative mean returns for Mondays and Fridays.

\begin{tabular}{|c|c|c|c|c|}
\hline Day & & ALGNF & ALINF & ALSNF \\
\hline Pre-holiday & Minimum return & $-4.89 \%$ & $-1.72 \%$ & $-1.61 \%$ \\
\hline \multirow[t]{7}{*}{ (PRE) } & Mean return & $0.47 \%$ & $0.24 \%$ & $0.38 \%$ \\
\hline & t-value & 1.468 & 1.078 & 1.947 \\
\hline & Significance level & 0.142 & $0.28 I$ & 0.0 .51 \\
\hline & Maximum return & $15.78 \%$ & $3.86 \%$ & $4.91 \%$ \\
\hline & Mean (WH excluded) & $0.49 \%$ & $0.18 \%$ & $0.33 \%$ \\
\hline & Median & $0.25 \%$ & $0.17 \%$ & $0.17 \%$ \\
\hline & Mann-Whitney -p & 0.171 & 0.461 & 0.165 \\
\hline Post-holiday & Minimum return & $-5.81 \%$ & $-3.45 \%$ & $-4.28 \%$ \\
\hline \multirow[t]{7}{*}{ (POST) } & Mean return & $-0.13 \%$ & $0.11 \%$ & $-0.01 \%$ \\
\hline & t-value & -0.444 & 0.172 & -0.461 \\
\hline & Significance level & 0.657 & 0.863 & 0.644 \\
\hline & Maximum return & $6.97 \%$ & $2.73 \%$ & $2.77 \%$ \\
\hline & Mean (WH excluded) & $-0.47 \%$ & $0.07 \%$ & $-0.12 \%$ \\
\hline & Median & $-0.33 \%$ & $0.07 \%$ & $-0.02 \%$ \\
\hline & Mann-Whitney -p & 0.439 & 0.687 & 0.711 \\
\hline Non-holiday & Minimum return & $-11.58 \%$ & $-12.60 \%$ & $-965 \%$ \\
\hline \multirow[t]{4}{*}{ (NONH) } & Mean return & $0.01 \%$ & $0.08 \%$ & $0.06 \%$ \\
\hline & Maximum return & $11.20 \%$ & $6.10 \%$ & $5.22 \%$ \\
\hline & Mean (WH excluded) & $0.02 \% \%$ & $0.09 \%$ & $0.07 \%$ \\
\hline & Median & $0.00 \%$ & $0.08 \%$ & $0.06 \%$ \\
\hline \multicolumn{5}{|l|}{ Mean return ratio: } \\
\hline PRE/NONH ratio & WH included & $40.25: 1$ & $2.92: 1$ & $6.18: 1$ \\
\hline PRE/NONH ratio & WH excluded & $21.24: 1$ & $2.06: 1$ & $4.88: 1$ \\
\hline
\end{tabular}

WH $=$ Weekend holidays (weekends with a holiday on Saturday or Sunday)

The ALINF median is $0.17 \%$ for pre-holiday returns and $0.07 \%$ for post-holiday returns, while the median for the non-holiday returns is $0.08 \%$. The difference in the medians is tested with the Mann-Whitney U-test. The $\mathrm{H}_{11}$ hypothesis is not rejected at the $5 \%$ significance level, as indicated by the Mann-Whitney $p$-values of 0.46 and 0.69

The ALSNF shows positive mean returns for all pre-holiday weekdays. The pre-holiday mean return is 6.2 times the mean return for non-holidays. Monday and Friday postholidays show a positive mean return. The non-holiday weekdays have negative mean returns for Mondays and Fridays.

The ALSNF median is $0.17 \%$ for pre-holiday returns and $-0.02 \%$ for post-holiday returns, while the median for the non-holiday returns is $0.06 \%$. The difference in the medians is tested with the Mann-Whitney U-test. The $\mathrm{H}_{1}$ hypothesis is not rejected at the $5 \%$ significance level, as indicated by the Mann-Whitney p-values of 0.16 and 0.71 .

The mean returns are positive for all three near futures on Tuesday and Wednesday pre-holidays and Monday postholidays. The mean returns on post-holidays are negative for Tuesday to Thursday. The non-holidays show positive mean returns for Thursday and negative mean returns for Monday. Friday non-holidays do not show a high positive mean return, as supported by the literature study. 
The minimum and maximum daily returns for the near futures are also presented in Table 5. The ALINF and the ALSNF show similar deviations for pre-holidays and postholidays. where these deviations are also smaller than the deviations for non-holidays. It therefore shows that although returns are higher on certain pre-holidays and postholidays, they are less volatile. The ALGNF pre-holiday shows the highest ratio of pre-holiday to non-holiday returns, but it also shows larger minimum and maximum value deviations than the other near futures contracts.

The mean returns for ALGNF change to $0.489 \%$ for preholidays. $-0.303 \%$ for post-holidays and $0.023 \%$ for the non-holidays, where the ten weekends with holidays are regarded as normal weekends. The pre-holiday/non-holiday ratio changes to 21.24:1. The mean return for the non-holidays doubled, while the mean return for pre-holidays remained the same. The ALINF and the ALSNF non-holiday mean returns also show an increase, with a corresponding decrease in the mean return for the pre-holiday. The postholiday mean returns are also smaller. The pre-holiday/ non-holiday ratio changes to $2.06: 1$ and $4.88: 1$ respectively The above results support the assumption of Fridays and Mondays of weekends with holidays, to be regarded as preholidays and post-holidays.

The ALGNF standard deviations vary between $2 \%$ and $5 \%$. Wednesdays show the highest standard deviation for pre-holidays and is also associated with the highest mean return for the week. The higher Wednesday mean return may be attributed to the increased risk of higher gains or losses, as the higher standard deviation is an indication of the higher risk in mean returns for Wednesdays. The rest of the days show a smaller or similar standard deviation than the normal trading on non-holidays.

According to the $\mathrm{H}_{4}$ hypothesis the standard deviations for the pre-holidays and post-holidays are equal to the standard deviation for non-holidays. The $\mathrm{H}_{4}$, hypothesis is not rejected at the $5 \%$ significance level for the ALGNF, with the pre-holiday standard deviation regarded as equal to the standard deviation for non-holidays. The $\mathrm{H}_{0}$ hypothesis is rejected at the $4.9 \%$ significance level for the ALGNF post-holiday standard deviation. The $\mathbf{H}_{10}$ hypothesis is also not rejected for the day-of-the-week standard deviations, except for the pre-holiday standard deviation for Wednesday. See Table 6 and Appendix A for the ALGNF statistical test results.

The ALINF standard deviations vary between $0.7 \%$ and $1.5 \%$. Most of the pre-holiday and post-holiday day-of-theweek standard deviations are smaller than the non-holiday standard deviations. This indicates that there is no extra benefit due to risk, as risk is evenly spread over the days of the week.

The equality of standard deviation $\mathrm{H}_{1}$ hypothesis is not rejected at the 5\% significance level for the ALINF, with the standard deviation for the post-holidays regarded as equal to the standard deviation for non-holidays. The $\mathbf{H}_{6}$ hypothesis is rejected for the pre-holiday standard deviation at the $0.7 \%$ significance level. The $\mathrm{H}_{0}$ hypothesis is also rejected for the pre-holiday standard deviations of Mondays and Thursdays at the 5\% significance level. See Table 6 and Appendix B.
Table 6 Difference between pre-holiday, post-holiday and non-holiday variances

\begin{tabular}{lccc}
\hline Comparison of variances & ALGNF & ALINF & ALSNF \\
\hline Pre-holidays versus non-holidays: & & & \\
$s_{1}{ }^{2} / s_{2}{ }^{2}$ & 1.284 & 1.559 & 1.228 \\
$\mathrm{~F}_{01125}$ (at $5 \%$ significance level) & 1.389 & 1.389 & 1.389 \\
$\mathrm{H}_{0}$ (accepted if variances are equal) & Accepted & Rejected & Accepled \\
Significance level & $1.3 .8 \%$ & $0.7 \%$ & $22.1 \%$ \\
\hline Post-holidays versus non-holidays: & & & \\
$\mathrm{s}_{1}{ }^{2} / \mathrm{s}_{2}{ }^{2}$ & 1.391 & 1.237 & 1.069 \\
$\mathrm{~F}_{111125}$ (at $5 \%$ significance level) & 1.389 & 1.389 & 1.389 \\
$\mathrm{H}_{0}$ (accepted if variances are equal) & Rejected & Accepted & Accepted \\
Significance level & $4.9 \%$ & $20.5 \%$ & $66.8 \%$ \\
\hline
\end{tabular}

The ALSNF standard deviations vary between $0.9 \%$ and $1.9 \%$. Most of the pre-holiday and post-holiday day-of-theweek standard deviations are smaller than the non-holiday standard deviation. This indicates that there is no extra benefit due to risk, as risk is evenly spread over the days of the week.

The $\mathrm{H}_{11}$ hypothesis is accepted at the $5 \%$ and significance level for the ALSNF, with the standard deviations for the pre-holidays and post-holidays regarded as equal to the standard deviation for non-holidays. It is only the ALSNF post-holiday standard deviation of Wednesday that is significantly higher than the standard deviation for non-holidays on Wednesday. The $\mathrm{H}_{11}$ hypothesis is rejected at the $2.4 \%$ significance level. The standard deviation of Tuesday pre-holidays are significantly higher than the standard deviation of Tuesday non-holidays, at the $1.5 \%$ significance level. The Thursday and Friday pre-holidays are significantly lower at the $2.7 \%$ and $0.9 \%$ significance level respectively. See Table 6 and Appendix C.

The day-of-the-week pre-holiday standard deviations are only significantly higher than the standard deviations of non-holidays for ALGNF on Wednesdays and for ALSNF on Tuesdays. The other day-of-the-week pre-holiday standard deviations for ALINF and ALSNF, which are significantly different, are significantly lower than the standard deviations of non-holidays. The mean returns are, however, not significantly different as shown in Table 5. It is therefore suggested that the higher pre-holiday mean returns are due to a few exceptionally high returns.

The frequency of daily gains and losses, or advances, for all three near futures are shown in Table 7. According to the $\mathrm{H}_{1}$, hypothesis the pre-holidays and the post-holidays should have similar frequencies of positive returns as the non-holiday returns. The test results have led to the non-rejection of the $H_{10}$ hypothesis, namely that all proportions are equal for the pre-holidays, post-holidays and the non-holidays for all three near futures. Detailed results of the hypothesis tests are available in Appendices A, B and C for the different near futures.

The results of the regression analysis are tabulated in Table 8 . 


\begin{tabular}{lcccccccccc}
\hline \multicolumn{1}{l}{ Table 7 Frequency of daily advances } & \multicolumn{1}{c}{ ALINF } & \multicolumn{3}{c}{ ALSNF } \\
\hline \multirow{3}{*}{ Daily returns } & PRE & POST & NONH & PRE & POST & NONH & PRE & POST & NONH \\
\hline Return = $=$ & Number & 4 & 3 & 48 & 5 & 4 & 82 & 2 & 1 & 74 \\
& \% of total & $6.3 \%$ & $4.7 \%$ & $2.9 \%$ & $7.8 \%$ & $6.3 \%$ & $4.9 \%$ & $3.1 \%$ & $1.6 \%$ & $4.4 \%$ \\
\multirow{2}{*}{ Return = } & Number & 36 & 31 & 846 & 41 & 38 & 966 & 39 & 32 & 9.34 \\
& \% of total & $56.3 \%$ & $48.4 \%$ & $50.6 \%$ & $64.1 \%$ & $59.4 \%$ & $57.7 \%$ & $60.9 \%$ & $50.0 \%$ & $55.8 \%$ \\
\multirow{3}{*}{ Positive } & Number & 32 & 28 & 798 & 36 & 34 & 884 & 37 & 31 & 860 \\
& \% of total & $50.0 \%$ & $43.8 \%$ & $47.7 \%$ & $56.3 \%$ & $53.1 \%$ & $52.8 \%$ & $57.8 \%$ & $48.4 \%$ & $51.4 \%$ \\
Negative & Number & 28 & 33 & 827 & 23 & 26 & 707 & 25 & 32 & 739 \\
& \% of total & $43.8 \%$ & $51.6 \%$ & $49.4 \%$ & $35.9 \%$ & $40.6 \%$ & $42.3 \%$ & $39.1 \%$ & $50.0 \%$ & $44.2 \%$ \\
\hline Sample size & & 64 & 64 & 1673 & 64 & 64 & 1673 & 64 & 64 & 167.3 \\
\hline
\end{tabular}

\begin{tabular}{|c|c|c|c|c|c|c|c|c|c|}
\hline \multirow{2}{*}{$\begin{array}{l}\text { Independent } \\
\text { variable } \\
\end{array}$} & \multicolumn{3}{|c|}{ ALGNF } & \multicolumn{3}{|c|}{ ALINF } & \multicolumn{3}{|c|}{ ALSNF } \\
\hline & Coefficient & t-value & Sig. level & Coefficient & $t$-value & Sig. level & Coefficient & $t$-value & Sig. level \\
\hline Constant & -0.000412 & -0.2985 & 0.7653 & -0.000342 & -0.5265 & 0.5986 & -0.00061 .5 & -0.8527 & 0.3938 \\
\hline Tuesday & -0.000331 & $-0,1785$ & 0.8583 & 0.001689 & 1.9378 & 0.0526 & 0.000916 & 0.9461 & 0.3441 \\
\hline Wednesday & 0.00106 & 0.5712 & 0.5679 & 0.001187 & 1.3602 & 0.1738 & 0.001036 & 1.0692 & 0.285 \\
\hline Thursday & 0.002068 & 1.1097 & $0.267 I$ & 0.00195 & $2.226 \#$ & $0.026 *$ & 0.002822 & $2.9009 *$ & 0.0037 * \\
\hline Friday & 0.000655 & 0.3494 & 0.7268 & -0.00016 & -0.1812 & 0.8562 & 0.000126 & 0.129 & 0.8973 \\
\hline January & -0.0039 & -1.9346 & 0.053 & -0.001156 & -1.2201 & 0.2224 & -0.00174 & -1.6531 & 0.0983 \\
\hline Pre-holiday & 0.003859 & 1.2079 & 0.2271 & 0.001288 & 0,8574 & 0.3912 & 0.002696 & 1.6161 & 0.1061 \\
\hline Post-holiday & -0.00157 & -0.494 & 0.6213 & 0.0000023 & 0.0015 & 0.9988 & -0.001048 & -0.6311 & 0.5279 \\
\hline Turn-of-the-month & 0.001012 & 0.7306 & 0.465 & 0.001426 & $2.1911 \#$ & 0.0284* & 0.001691 & $2.3389 \#$ & 0.0193 \# \\
\hline$R^{2}$ & 0.004908 & - & - & 0.009641 & - & - & 0.012982 & - & - \\
\hline$R^{2}$ (Adjusted) & 0.000455 & - & - & 0.005210 & - & - & 0.008566 & - & - \\
\hline Durbin-Watson & 2.01318 & - & - & 1.95354 & - & - & 1.99225 & - & - \\
\hline F-Ratio of model & 1.1023 & - & 0.3584 & 2.17581 & - & $0.0267 *$ & 2.93962 & - & $0.0029 *$ \\
\hline Standard error of estimate & $0.02476 \mathrm{I}$ & - & - & 0.011640 & - & - & 0.012928 & - & - \\
\hline MAE $=$ & 0.018353 & - & - & 0.007883 & - & - & 0.009217 & - & - \\
\hline
\end{tabular}

The regression model of the ALGNF shows that none of the variables are significant, although the month of January becomes significant at the $5.3 \%$ level. Both Thursday and the turn-of-the-month variables are significant in the ALINF regression model, with a significance level of $2.6 \%$ and $2.84 \%$ respectively. The ALSNF regression model indicates the Thursday variable to be significant at the $0.37 \%$ level and the turn-of-the-month variable at $1.93 \%$. January is only significant at the $10 \%$ level. None of the regression models show that the pre-holiday or post-holiday variables are significant for any of the near futures contracts.

It does not make much difference to the model whether the ten weekends, with Friday pre-holidays and Monday post-holidays, are excluded or not.

The mean and median returns were determined for each of the three trading days before a holiday, the two trading days following a holiday, as well as the mean return for the non-holidays. See Table 9 for these results of the ALGNF, ALINF and the ALSNF. Results from Bhana's study (1994: 47) on the JSE shares are also included in Table 9.
The mean returns for all three near futures show an increase on the three days prior to a holiday, with the largest mean return on the pre-holiday. The post-holidity period is followed by lower or even negative mean returns. The ALINF and the ALSNF compare favourably with the normal trading on non-holidays. A post-holiday effect therefore does not appear to be present.

The ALGNF shows only positive mean returns for the two days prior to the holidays. These returns are much more positive than the non-holiday mean returns. The third day prior to the holiday and the two days following a holiday show large negative mean returns. It appears as if a negative post-holiday period may exists, but only for the ALGNF.

The ALINF shows positive returns for the days immediately before and after a public holiday. The third day hefore the holiday and the two days following the holiday compare well with the non-holiday mean return. The ALSNF shows only a small negative mean return on the trading day following the holiday. 


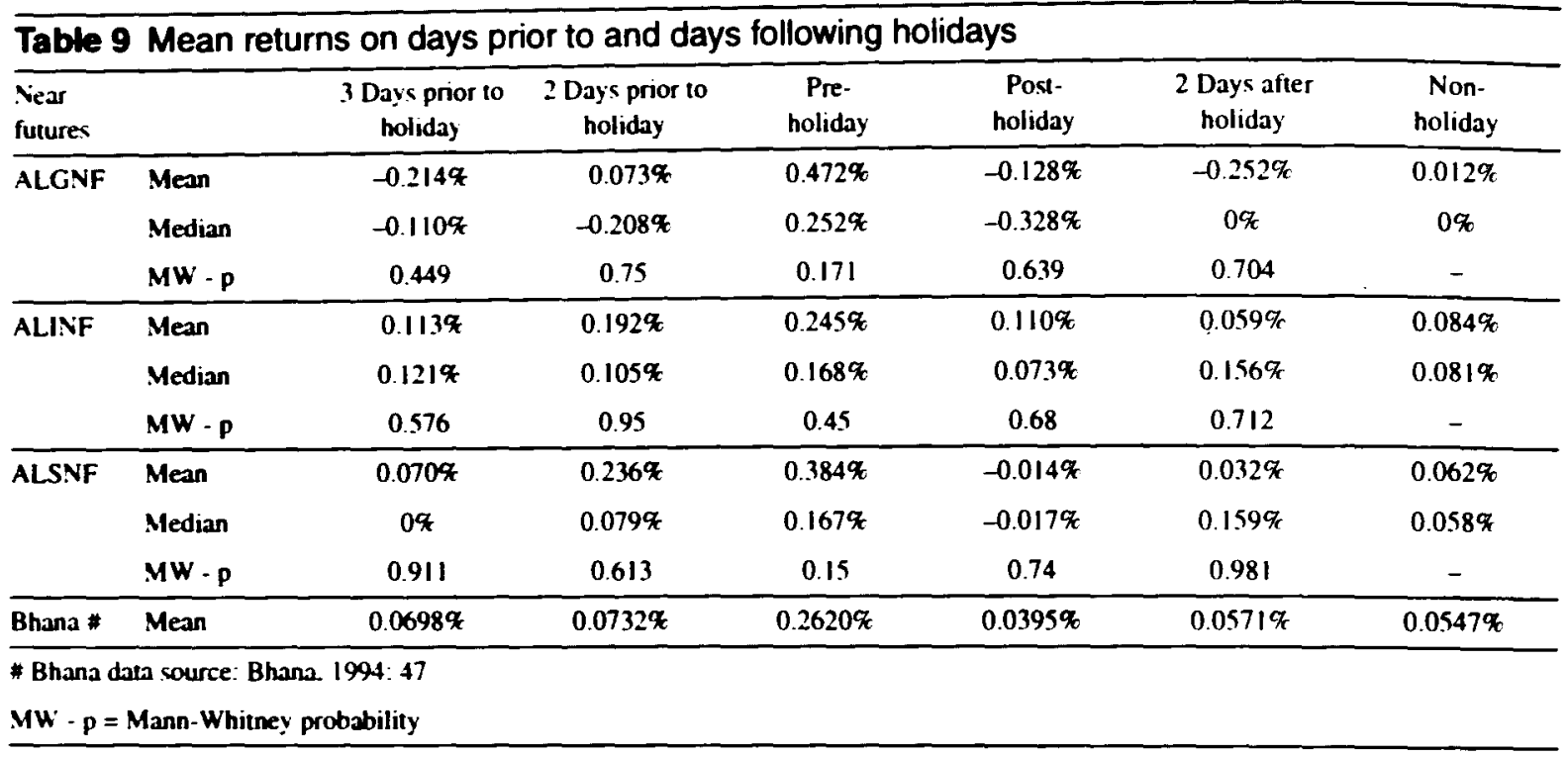

The unpaired Mann-Whitney (MW) U-test is used to calculate the test statistic $Z$ for the average ranks of the days before and after a holiday. The difference in median returns are not significant at the $5 \%$ level. The median returns of the second day before a holiday and the second day after a holiday are not significantly different from non-holiday media returns either. Therefore, these results do not support a significant holiday effect.

The cumulative returns for the ALGNF. ALINF and ALSNF for the period 5 January 1988 to 10 March 1995 are summarised in Table 10. A cumulative return is defined as the sum of the daily non-inflation adjusted returns over the total sampling period, in terms of the actual near futures contract values. The cumulative return of -189 for all the days of the ALGNF therefore reflects that the ALGNF contract dropped from 1769 on 5 January 1988 to 1580 on 10 March 1995.

The results are summarised as follows:

a. Positive cumulative returns for the pre-holidays are found for all three near futures. The pre-holiday cumulative returns contributed to $17.6 \%$ of the total ALINF returns and $31.3 \%$ of the total ALSNF returns. The preholidays are only $3.6 \%$ of the total trading days, indicating that the total pre-holiday returns are not proportional to the number of trading days.

The cumulative return for the ALGNF is positive for the pre-holidays while it is negative for the non-holidays. This highlights the importance of the holiday effect in the ALGNF.

b. Pre-holiday returns are higher than post-holiday returns.

c. The ALINF and the ALSNF both show that the postholiday cumulative returns are strongly influenced by the positive pre-holiday returns. Four of the trading days may be regarded as pre-holidays and post-holidays, with pre-holidays taking preference. The ALGNF however, shows that the same four days influenced the cumulative post-holiday returns more negatively.

\begin{tabular}{|c|c|c|c|c|}
\hline Contract & All days & Pre-holiday & Post-holiday & Non-holiday \\
\hline \multicolumn{5}{|l|}{ ALGNF } \\
\hline Cumulative return & -189 & $49 !$ & -69 & -611 \\
\hline F of All day return & - & $(+)$ & - & $(-)$ \\
\hline Post-holidays (including 4 pre-holidays) & - & - & -93 & - \\
\hline \multicolumn{5}{|l|}{ ALINF } \\
\hline Cumulative return & 5051 & 891 & 169 & 3991 \\
\hline$q$ of All day return & - & $17.64 \%$ & - & $79.01 \%$ \\
\hline Post-holidays (including 4 pre-holidays) & - & - & 453 & - \\
\hline \multicolumn{5}{|l|}{ ALSNF } \\
\hline Cumulative return & 3418 & 1071 & -53 & 2400 \\
\hline$q$ of All day return & - & $31.33 \%$ & - & $70.22 \%$ \\
\hline Post-holidays (including 4 pre-holidays) & - & - & 272 & - \\
\hline Trading days & 1797 & 64 & 64 & 1673 \\
\hline Proportion of total days & - & $3.56 \%$ & - & $93.10 \%$ \\
\hline
\end{tabular}




\begin{tabular}{llcccc}
\hline Table 11 & Holidays and the turn-of-the-month & (or month-end) & effects & \\
\hline Near & Statistical & Pre-holiday + & Post-holiday + & Non-holiday + & All days \\
future & description & month-end & month-end & month-end & inonth-end \\
\hline ALGNF & Mean return & $0.321 \%$ & $-0.400 \%$ & $0.130 \%$ & $0.113 \%$ \\
& Median & $0.576 \%$ & $-0.821 \%$ & $0.077 \%$ & $0 \%$ \\
& Mann-Whitney - p & 0.585 & 0.083 & - & - \\
& Standard deviation & $1.905 \%$ & $2.598 \%$ & $2.219 \%$ & $2.216 \%$ \\
\hline ALINF & Mean return & $0.184 \%$ & $0.073 \%$ & $0.219 \%$ & $0.202 \%$ \\
& Median & $0.195 \%$ & $0 \%$ & $0.177 \%$ & $0.172 \%$ \\
& Mann-Whitney - p & 0.764 & 0.395 & - & - \\
& Standard deviation & $0.880 \%$ & $0.858 \%$ & $1.120 \%$ & $1.097 \%$ \\
\hline ALSNF & Mean return & $0.197 \%$ & $-0.014 \%$ & $0.232 \%$ & $0.204 \%$ \\
& Median & $0.140 \%$ & $-0.037 \%$ & $0.234 \%$ & $0.167 \%$ \\
& Mann-Whitney - p & 0.549 & 0.336 & - & - \\
& Standard deviation & $0.882 \%$ & $1.256 \%$ & $1.259 \%$ & $1.234 \%$ \\
\hline
\end{tabular}

d. The post-holiday returns for the ALGNF are negative, as it is for non-holidays, and even for the sampling period over all.

The pre-holidays are $7.2 \%$ of the total turn-of-the-month trading days. The mean returns of the pre-holidays and post-holidays of all three near futures do not differ significantly from the turn-of-the-month non-holidays. The ALGNF standard deviations of the pre-holidays and postholidays do not differ significantly from the turn-of-themonth non-holiday standard deviation. Only the ALSNF pre-holiday standard deviation and the ALINF post-holiday standard deviation differ significantly from the non-holiday standard deviation, at the 5\% significance level. The statistics and test results are available in Appendix $\mathrm{A}$ to $\mathrm{C}$, with some results summarised in Table 11 .

The ALGNF pre-holiday turn-of-the-month mean return is higher than the mean return for the non-holidays, but not significantly so. The mean returns for the ALINF and ALSNF on pre-holidays are equal to the mean returns on the non-holidays. The standard deviations are actually smaller for all three near futures for the pre-holidays as compared to the non-holidays. It is therefore concluded that the preholidays do not contribute significantly to the turn-of-themonth effect. These two seasonal anomalies both exist in their own right.

\section{Conclusions}

The mean and median returns of the daily returns before and after a holiday were analysed, as well as the cumulative returns of the near futures contract indices. The pre-holidays showed higher mean and median returns for all three near futures contracts. None of these near future returns were significantly different from the mean and median returns for non-holidays. The cumulative returns for preholidays contributed much more to the overall cumulative return of the near futures than the proportion of pre-holidays of total trading days. The regression analysis of the near futures have not shown any significant pre-holiday or post-holiday effect in the South African futures market.
The holiday effect does not influence the significance of the turn-of-the-month effect. It is concluded that both these seasonal anomalies exist in their own right in the South African futures market.

It is finally concluded that the holiday effects are not large enough to be exploited on an ongoing basis in the South African futures market. to really benefit the active traders and investors. The pre-holiday returns are not sufficient reward for taking extra risk of trading on a specific pre-holiday. Investors who want to trade around the holidays anyway, may utilise the opportunities. The seller could benefit by the pre-holiday higher mean returns on specific days, while the buyer may benefit from trading on the post-holidays with lower prices.

\section{References}

Ariel. R.A. 1987. A monthly effect in stock returns. Journal of $F i$. nancial Economics. 18: 161-174.

Ariel. R.A. 1990. High stock returns before holidays: existence and evidence on possible causes. Journat of Finance. 45(5): 1611-1626

Bhana. N. 1985. The Monday effect on the Johannesburg Stock Exchange. South African Journal of Business Management. 16(1): 7-11.

Bhana. N. 1994. Public holiday share price behaviour on the Johannesburg Stock Exchange, Investment Analysts Journal. 39 $45-49$.

Bradfield. D.J. 1990. A note on the seasonality of stock returns on the Johannesburg Stock Exchange. South African Journal of Business Management. 21(1): 7-9.

Chang. E.C., Jain. P.C. \& Locke. P.R. 1995. Standards and Poors 500 Index futures volatility and price changes around the New York Stock Exchange close. Journal of Business. $68(1)$ : 61-84.

Chiang. R. \& Tapley. C. 1983. Day-of-the-week effects in the futures market. Revien' of Research in Futures Markets. 2(3): 356-410

Cornell. B. 1985. The weekly pattern in stock returns: cash iersus futures: a note, Journal of Finance, 40(2): 583-588.

Davidson. S. \& Meyer. S. 1993. The Monday effect and the Johannesburg Stock Exchange revisited. South African Journal of Business Management, 24(3): 8.3-87. 
Fabozzi. F.J. \& Ma. C.K. \& Briley. J.E. 1994. Holiday trading in futures markets. Joumal of Finance, 49(1): 307-324.

Hatingh. F.S. \& Smit E.v.d.M. 1993. Seisoenale patrone in die Suid-Afrikaanse kapitaalmark. South African Joumal of Business Manogement. 24(4): 142-146.

Johnston. E T. \& Kracaw. W.A. \& McConnell. J.J. 1991. Day-ofthe-week effects in financial futures: an analysis of GNMA. TBond. T-Note. and T-Bill contracts. Joumal of Financial and Quantitative Analysis. 26(1): 23-44.

Jordan. S.D. \& Jordan. B.D. 1991. Seasonality in daily bond returns. Joumal of Financial Quantitaive Anal ysis. 26: 269-285.

Khaksari. S. \& Bubnys. E.L. 1992. Risk-adjusted day-of-theweek. day-of-the-month. and month-of-the-year effects on stock indexes and stock index futures. Financial Review. 27(4): $531-552$

Kim. C-W. \& Park. J. 1994. Holiday effects and stock returns: further evidence. Joumal of Financial and Quantitative Anahysis. 2911): 145-157.
Nash, P. 1994. The weekend effect on the Johannesburg Stock Ex. change. A thesis presented to the Business Science Department, University of Cape Town. pl00.

Peuengill. G.N. 1989. Holiday closings and security returns. Jour. nal of Financial Research, 12(1): 57-67

Pettengill. G.N. \& Jordan, B.D. 1988. A comprehensive examination of volume effects and seasonality in daily security retums. Journal of Financial Research. 11(1): 57-70.

Rogalski, R.J. 1984. New findings regarding day-of-the-week returns over trading and non-trading periods: a note. Journal of Finance. 39(5): 1603-1614.

Thaler, R. 1987. Seasonal movements in security prices II: weekend. holiday, tum of the month and intraday effects. Economic Perspectives. 1(1): 169-177.

Watson. G. \& Smit E.vd.M. 1994. Seasonal patterns in the South African share index futures market. South African Joumal of Business Management. 25(4): 155-161. 
Appendix A All Gold Near Futures statistical analysis results

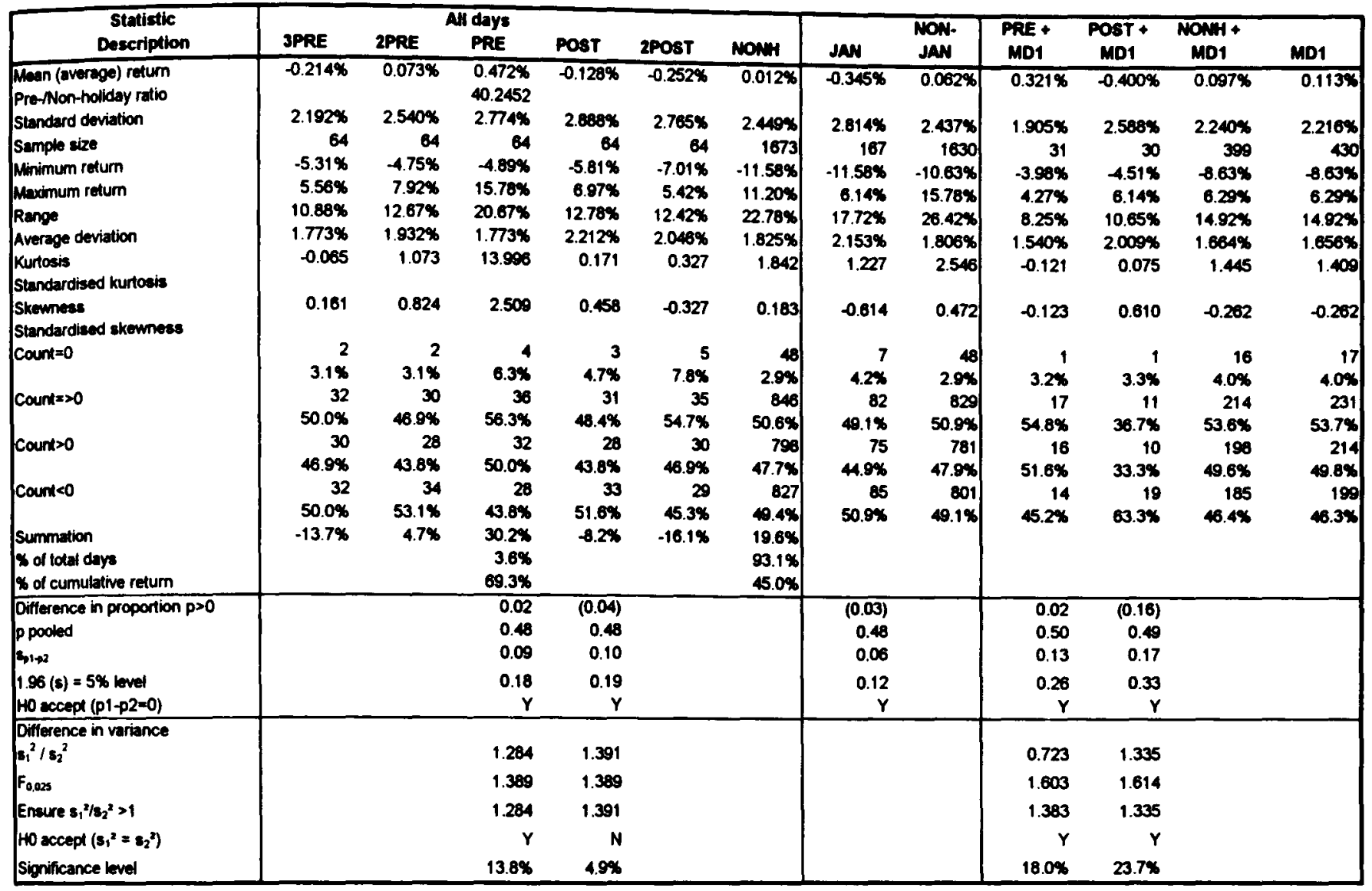

\begin{tabular}{|c|c|c|c|c|c|c|c|c|c|c|c|c|c|c|c|c|}
\hline Sintistic & Daily & & londay & & & Tuesoday & & & Wedrescidy & & & Thereday & & & indayy & \\
\hline & return & PRE & POST & NONH & PRE & POST & NONH & PRE & POST & NONH & PRE & POST & MONH & PRE & POST & NONH \\
\hline Meen (average) refturn & $0.024 \%$ & $0.892 \%$ & $1.181 \%$ & $-0.148 \%$ & $0.780 \%$ & $-1.285 \%$ & $-0.058 \%$ & $1.086 \%$ & $-0.209 \%$ & $0.035 \%$ & $0624 \%$ & $-0726 \%$ & $0187 \%$ & -00728 & $.0225 \%$ & \\
\hline atio & & & & & & & & & & & & & & & & \\
\hline $\begin{array}{l}\text { Stundard devisation } \\
\text { Semple size }\end{array}$ & $2.477 x$ & $2.095 \%$ & $3.178 \%$ & $2.648 \%$ & $2.521 \%$ & $1.936 \%$ & 2.2178 & $5.120 \%$ & $3.444 \%$ & $\begin{array}{r}2.4318 \\
347\end{array}$ & $\begin{array}{r}1.913 \% \\
15\end{array}$ & $\begin{array}{l}3.797 \% \\
8\end{array}$ & $2.605 \%$ & ${ }_{25}^{1.998 \%}$ & $1.716 \%$ & $2.322 x$ \\
\hline $\begin{array}{l}\text { SAmple size } \\
\text { Minimum return }\end{array}$ & $\begin{array}{r}1797 \\
-11.58 \%\end{array}$ & $\begin{array}{r}5 \\
-1.75 \%\end{array}$ & $\begin{array}{r}20 \\
-4.85 \%\end{array}$ & $\begin{array}{r}325 \\
-10.63 \%\end{array}$ & $\begin{array}{r}8 \\
-3.96 \%\end{array}$ & $\begin{array}{r}17 \\
-4.51 \%\end{array}$ & $\begin{array}{r}340 \\
-6.06 \%\end{array}$ & $\begin{array}{r}14 \\
-4.03 \%\end{array}$ & $-5.27 \%$ & $\begin{array}{r}347 \\
.7 .75 \%\end{array}$ & $\begin{array}{r}15 \\
-3.83 \%\end{array}$ & $\begin{array}{r}8 \\
-5.81 \%\end{array}$ & $\begin{array}{r}3386 \\
.11 .58 \%\end{array}$ & $-4.29 \%$ & $-256 \%$ & $\begin{array}{r}3234 \\
-8.63 \%\end{array}$ \\
\hline Mevimum return & $15.78 \%$ & $3.99 \%$ & $6.78 \%$ & $\begin{array}{r}9.25 \% \\
\end{array}$ & $4.27 \%$ & $1.93 \%$ & $10.54 \%$ & $15.78 \%$ & $6.14 \%$ & $10.10 x$ & $3.25 \%$ & $6.97 \%$ & $11.20 \%$ & $3.05 \%$ & $3.50 \%$ & $11.01 x$ \\
\hline Range & $27.36 \%$ & $5.74 x$ & $11.63 \%$ & 19.88\% & $8.25 \%$ & $6.44 \%$ & $16.60 x$ & $19.82 \%$ & $11.41 \%$ & $17.85 \%$ & $7.08 \%$ & $12.78 \%$ & $22.78 \times$ & 8.54\% & $6.00 \%$ & $19.64 \times$ \\
\hline Avercepe devitation & $1836 \%$ & $1.423 \%$ & $2.475 \%$ & $1.990 \%$ & $1.661 \%$ & $1.530 \%$ & $1.872 x$ & $2.822 \%$ & $2.468 \%$ & $1.818 \times$ & $1.400 \%$ & $2.520 \%$ & $1.934 \times 6$ & $1.495 \%$ & $1.318 \%$ & $1.710 \%$ \\
\hline 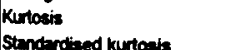 & 2.446 & 1.148 & -0.372 & 1.341 & 1.285 & -0.795 & 1.425 & 8.485 & 0.894 & 1.562 & 0.867 & 2.183 & 2.423 & 0.475 & 0.977 & 2.078 \\
\hline Strawneas & 0.312 & 0.482 & -0.229 & -0.100 & -0.517 & -0.109 & 0.355 & 2.732 & 0.573 & 0.280 & -1.127 & 1.042 & 0.122 & -0.091 & 0.852 & 0.416 \\
\hline 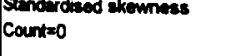 & $\begin{array}{r}5.400 \\
55\end{array}$ & & & & & & & & & & & 0 & 10 & 1 & 000 & 10 \\
\hline Canteso & $\begin{array}{l}3.14 \\
911 \\
9000\end{array}$ & $20.0 \%$ & $\begin{array}{r}5.0 \% \\
15\end{array}$ & $\begin{array}{l}2.226 \\
154\end{array}$ & $\begin{array}{r}12.5 \% \\
8\end{array}$ & $\begin{array}{r}5.9 \% \\
5\end{array}$ & $\begin{array}{r}3.28 \\
156 \\
48.5 \%\end{array}$ & $\begin{array}{r}0.0 \% \\
5 \\
5.5 \%\end{array}$ & $\begin{array}{r}12.5 \% \\
50.0 \%\end{array}$ & $\begin{array}{r}2.9 \% \\
184 \\
53.04\end{array}$ & $\begin{array}{r}6.7 \% \\
111 \\
73.34\end{array}$ & $\begin{array}{r}0.0 \% \\
2 \\
25.0 \%\end{array}$ & $\begin{array}{r}178 \\
52.14\end{array}$ & $\begin{array}{r}10 \\
40.0 \%\end{array}$ & $\begin{array}{r}5 \\
5 \\
455 \%\end{array}$ & $\begin{array}{r}167 \\
51.78\end{array}$ \\
\hline Countso & $\begin{array}{r}50.78 \\
856\end{array}$ & ${ }_{3}^{80.0 \%}$ & $\begin{array}{r}75.0 \% \\
14\end{array}$ & $\begin{array}{r}47.46 \\
147\end{array}$ & $\begin{array}{r}75.0 \% \\
5\end{array}$ & $\begin{array}{r}29.4 \% \\
4\end{array}$ & $\begin{array}{r}48.5 \% \\
154\end{array}$ & $\begin{array}{r}45.5 \% \\
5\end{array}$ & 3 & 174 & 10 & 2 & 160 & & & 157 \\
\hline counk $=0$ & $\begin{array}{r}47.6 \% \\
886\end{array}$ & $\begin{array}{r}60.0 \% \\
1\end{array}$ & $\begin{array}{r}70.0 \% \\
5\end{array}$ & $\begin{array}{r}45.2 \% \\
171\end{array}$ & $\begin{array}{r}62.5 \% \\
2\end{array}$ & $\begin{array}{r}23.5 \% \\
12\end{array}$ & $\begin{array}{r}45.34 \\
175\end{array}$ & $\begin{array}{r}45.5 \% \\
6\end{array}$ & $37.5 \%$ & $\begin{array}{l}50.1 \% \\
183\end{array}$ & $66.7 \%$ & $\begin{array}{r}25.0 \% \\
8\end{array}$ & $\begin{array}{r}49.19 \\
162 \\
1702\end{array}$ & $\begin{array}{r}36.0 \% \\
15\end{array}$ & $\begin{array}{r}45.5 \% \\
6\end{array}$ & $\begin{array}{c}40.6 \times \\
156\end{array}$ \\
\hline $\begin{array}{l}\text { Summation } \\
\text { xol total daye }\end{array}$ & $\begin{array}{l}49.3 \% \\
43.6 \%\end{array}$ & $20.0 \%$ & $25.0 \%$ & & $25.0 \%$ & & & & & & & & & & & \\
\hline & & & & & & & & 1005 & 0.131 & & 0.18 & $(0.24)$ & & $(0.13)$ & & \\
\hline $\begin{array}{l}\text { limberences in proportion p>0 } \\
\text { p poond }\end{array}$ & & $\begin{array}{l}0.15 \\
0.46\end{array}$ & $\begin{array}{l}0.25 \\
0.47\end{array}$ & & $\begin{array}{l}0.17 \\
0.46\end{array}$ & $\begin{array}{r}(0.22) \\
0.45 \\
0.29\end{array}$ & & $\begin{array}{l}0.50 \\
0.25\end{array}$ & $\begin{array}{l}0.50 \\
0.36\end{array}$ & & $\begin{array}{l}0.50 \\
0.17\end{array}$ & $\begin{array}{l}0.49 \\
0.50\end{array}$ & & $\begin{array}{l}0.48 \\
0.18\end{array}$ & $\begin{array}{l}0.49 \\
0.25\end{array}$ & \\
\hline $\sin _{142}$ & & 0.35 & 0.14 & & 0.25 & 0.29 & & 0.25 & 0.36 & & 0.17 & & & & 0.20 & \\
\hline 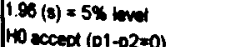 & & 0.69 & 0.28 & & 0.49 & $\begin{array}{r}0.57 \\
y\end{array}$ & & $\begin{array}{r}0.50 \\
Y\end{array}$ & $\begin{array}{r}0.70 \\
Y\end{array}$ & & $\begin{array}{r}0.34 \\
Y\end{array}$ & $\begin{array}{r}0.98 \\
Y\end{array}$ & & $\begin{array}{r}0.35 \\
\gamma\end{array}$ & $\begin{array}{r}0.50 \\
Y\end{array}$ & \\
\hline Difierences in variesce & & & & & & & & & & & & & & & & \\
\hline$s_{1}^{2} / s_{2}^{2}$ & & 0.626 & 1.440 & & 1.293 & 0.762 & & 4.438 & 2.008 & & 0.539 & 2.125 & & 0.741 & $0.5 \times 6$ & \\
\hline$F_{0,000}$ & & 2.607 & $1.7 \pi 2$ & & 2.326 & 1.843 & & 2.006 & 2.325 & & 1.905 & 2.325 & & 1.605 & 2.000 & \\
\hline Enaure $5,1 / s_{2}^{2}>1$ & & 1.597 & 1.440 & & 1.293 & 1.312 & & 4.438 & 2.000 & & 1.854 & 2.125 & & 1.360 & 1.831 & \\
\hline Ho accept $\left(s_{1}^{2}=s_{2}^{2}\right)$ & & $Y$ & Y & & Y & $\checkmark$ & & N & $Y$ & & r & Y & & Y & & \\
\hline SSigorificance lever & & $35.0 \%$ & $21.2 x$ & & $50.6 \%$ & 37.48 & & $0.0 \%$ & $10.7 \%$ & & $6.1 \%$ & $8.1 \%$ & & $25.9 \%$ & $10.9 \%$ & \\
\hline
\end{tabular}


Appendix B All Industrial Near Futures statistical analysis results

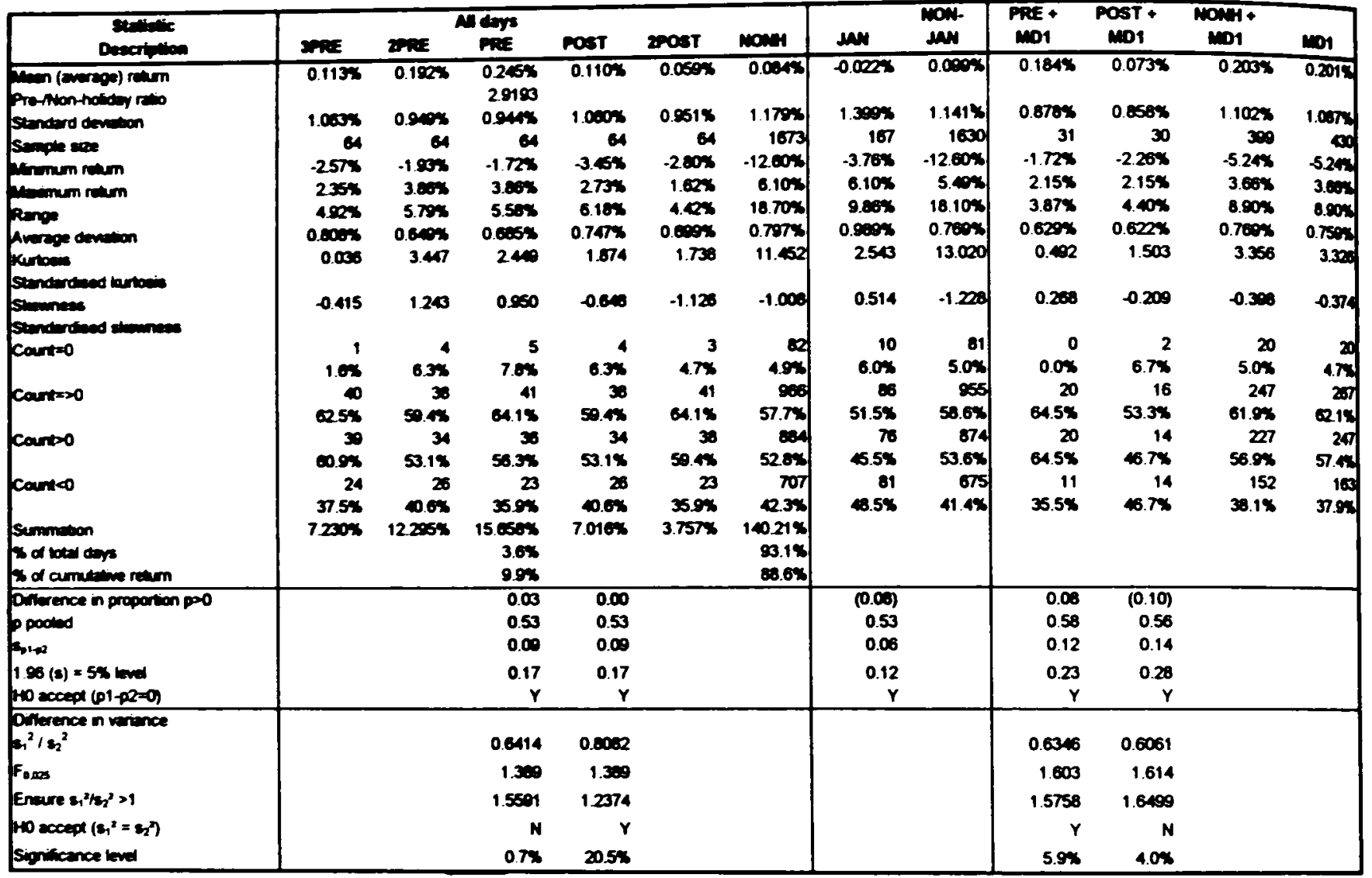

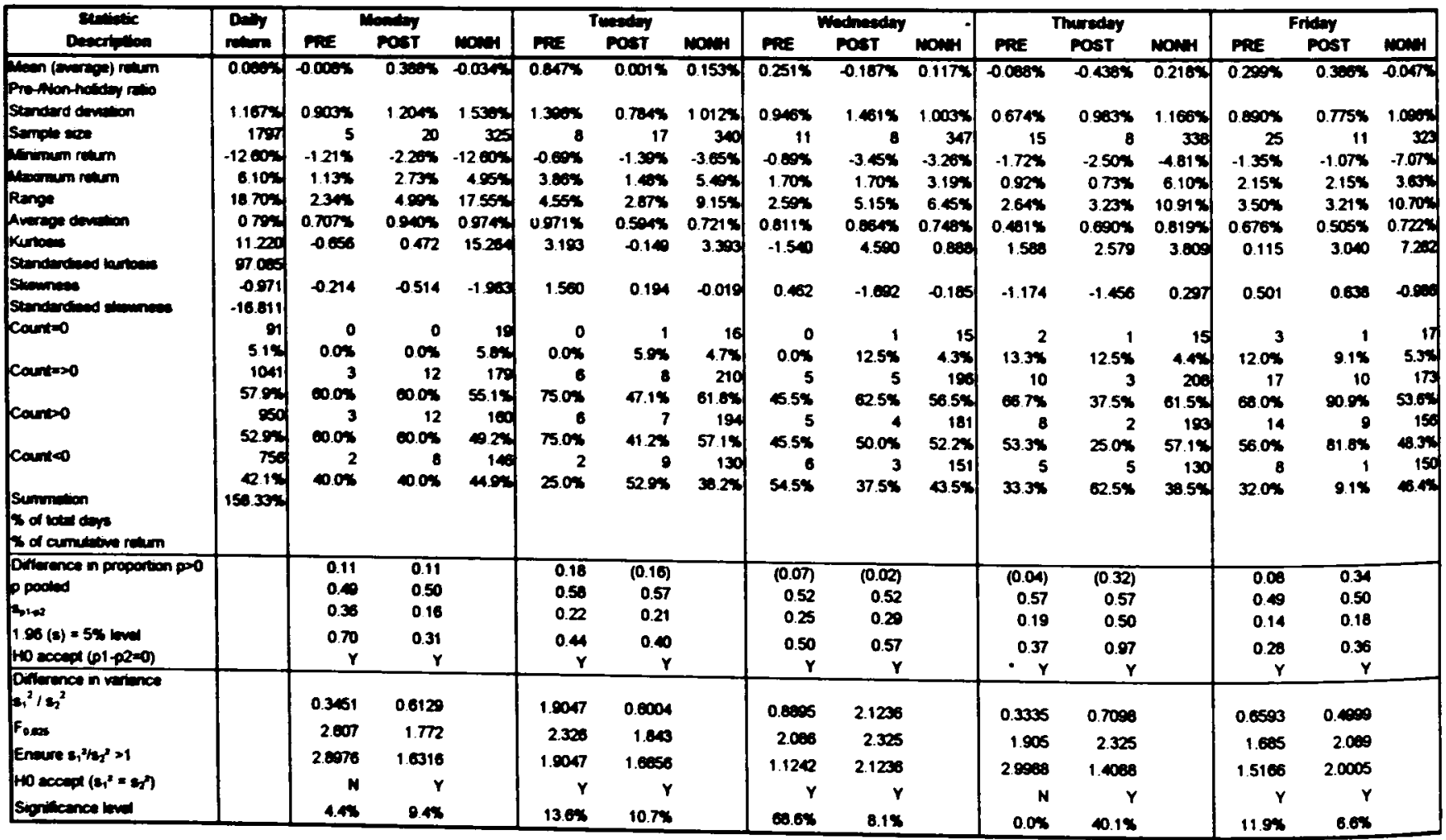


Appendix C All Share Near Futures statistical analysis results

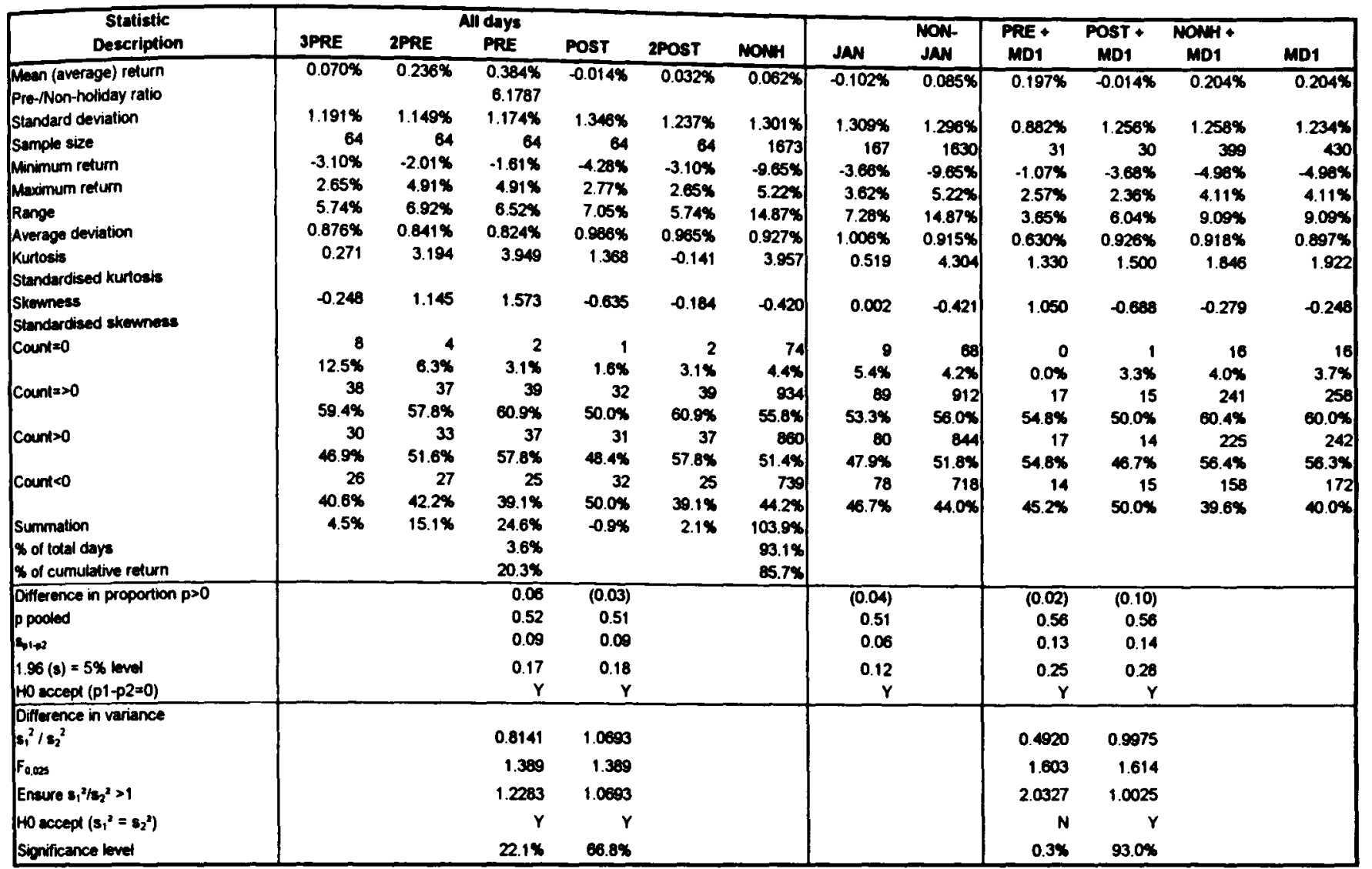

\begin{tabular}{|c|c|c|c|c|c|c|c|c|c|c|c|c|c|c|c|c|}
\hline Stmisstic & iny & & londay & & & Wesday & & & Fodreaday & & & Theresday & & & ay & \\
\hline Des: & & PRE & & ONH & PRE & & ONA & PRE & & моми & PRE & TT & 10014 & PRE & OST & ons \\
\hline Then (averag & & $0.275 \%$ & $0.459 \%$ & $-0.076 \times$ & $0.718 \%$ & $-0.262 \%$ & $0.059 x$ & $0.580 x$ & $0.119 \%$ & $0.064 x$ & $0.375 \%$ & .0 .0534 & $0.276 \times$ & $0.214 x$ & $0.193 x$ & $021 \%$ \\
\hline $\begin{array}{l}\text { Standerd deviation } \\
\text { Semple size }\end{array}$ & $\begin{array}{r}1.298 \% \\
1.797\end{array}$ & $\begin{array}{r}1.222 \% \\
5\end{array}$ & $\begin{array}{r}1.357 \% \\
20\end{array}$ & 1.5964 & $\begin{array}{r}914 \% \\
8\end{array}$ & $0.099 \%$ & $\begin{array}{r}1.1446 \\
340\end{array}$ & $1.553 \%$ & $\begin{array}{r}1.931 \% \\
8\end{array}$ & $\begin{array}{r}1.1928 \\
347\end{array}$ & $\begin{array}{r}0.930 \% \\
15\end{array}$ & $.631 \%$ & $\begin{array}{r}1.336 \% \\
338\end{array}$ & $0.830 \%$ & $\begin{array}{r}0.985 \% \\
11\end{array}$ & $\begin{array}{r}1.179 \\
37\end{array}$ \\
\hline mple size & $-9.65 \%$ & $-0.89 \%$ & $-2.18 \%$ & $-9.65 \%$ & $-1.20 \%$ & $.2 .01 \%$ & $-5.70 \%$ & $-1.38 \%$ & $-4.28 \%$ & $-3.85 \%$ & $-1.07 \%$ & $-3.68 \%$ & $-6.03 x$ & $-1.61 \%$ & $-1.12 \%$ & $-4 . x$ \\
\hline vimu & $5.22 \%$ & $2.35 \%$ & $2.77 \%$ & $5.22 \%$ & $4.91 \%$ & $129 \%$ & $5.04 \%$ & 4.27\% & $2.00 \%$ & $3.41 \%$ & $57 \%$ & $0.99 \%$ & $.78 \%$ & 6x & $2.30 x$ & 4.8 \\
\hline morege deviation & $\begin{array}{l}14.87 \% \\
0.923 \%\end{array}$ & $\begin{array}{r}3.23 \% \\
0.828 \%\end{array}$ & $\begin{array}{r}4.95 \% \\
1.127 \%\end{array}$ & $\begin{array}{l}14.878 \\
1.1008\end{array}$ & $\begin{array}{r}6.11 \% \\
1.321 \%\end{array}$ & $\begin{array}{r}3.30 \% \\
0.712 \%\end{array}$ & $\left.\begin{array}{l}10.74 \% \\
0.810 x\end{array}\right]$ & $\begin{array}{r}5.62 x \\
1.140 x\end{array}$ & $\begin{array}{r}6.29 \% \\
1.203 \%\end{array}$ & $\begin{array}{r}7.26 \% \\
0.893 \%\end{array}$ & $\begin{array}{r}3.65 \% \\
0.670 \%\end{array}$ & $\begin{array}{r}4.67 \% \\
1.240 \%\end{array}$ & $\begin{array}{l}10.81 \% \\
0.9648\end{array}$ & $\begin{array}{l}3.97 \% \\
0.565 \%\end{array}$ & $\begin{array}{r}3.49 \% \\
0.609 \%\end{array}$ & $\begin{array}{r}9.82 \% \\
0.032 \%\end{array}$ \\
\hline $\begin{array}{l}\text { Kurtocis } \\
\text { Stundardied kuto }\end{array}$ & $\begin{array}{r}3.903 \\
33775\end{array}$ & $\mathbf{3 . 3 6 7}$ & 0.758 & 5.305 & 3.499 & -0.295 & 3.557 & 2.388 & 3.345 & 0.868 & 1.286 & -0.096 & 2.197 & 1.760 & 1.277 & 255 \\
\hline emness: & -0.380 & 1.638 & -0.228 & -0.950 & 1.606 & -0.242 & -0.230 & 1.318 & -1.480 & -0.187 & 0.705 & -1.023 & -0.155 & 0.687 & 1.053 & 0.21 \\
\hline $\begin{array}{l}\text { Standar } \\
\text { Countac }\end{array}$ & $\begin{array}{r}-6.584 \\
77 \\
4.38\end{array}$ & $\begin{array}{r}0 \\
0.0 \%\end{array}$ & $0.0 \%$ & $\begin{array}{r}14 \\
4.34\end{array}$ & $0.0 \%$ & $0.0 \%$ & $\begin{array}{r}18 \\
4.7 \%\end{array}$ & $0.0 \%$ & $12.5 x^{\prime}$ & $\begin{array}{r}15 \\
4.35\end{array}$ & $6.7 x^{1}$ & $\begin{array}{r}0 \\
0.0 \%\end{array}$ & $\begin{array}{r}12 \\
3.6 \%\end{array}$ & $4.0 \%$ & $\begin{array}{r}0 \\
0.0 \%\end{array}$ & . \\
\hline Count $=>0$ & $\begin{array}{r}1001 \\
55.74\end{array}$ & $40.0 x^{2}$ & $\begin{array}{r}12 \\
60.0 \%\end{array}$ & $\begin{array}{r}177 \\
52.64\end{array}$ & $\begin{array}{r}5 \\
62.5 \%\end{array}$ & $41.2 x^{7}$ & $\begin{array}{r}199 \\
58.5 \% \\
\end{array}$ & $\begin{array}{r}5 \\
4.5 \%\end{array}$ & $50.0 x^{4}$ & $\begin{array}{r}190 \\
54.84\end{array}$ & $\begin{array}{r}11 \\
73.3 \%\end{array}$ & $37.5 x^{3}$ & $\begin{array}{r}206 \\
60.94\end{array}$ & $\begin{array}{r}16 \\
64.0 \%\end{array}$ & $54.5 x^{\circ}$ & 52. \\
\hline Count 20 & $\begin{array}{r}924 \\
51.44\end{array}$ & 2 & $\begin{array}{r}12 \\
600 \%\end{array}$ & $\begin{array}{r}157 \\
4838\end{array}$ & $\begin{array}{r}5 \\
62.5 \%\end{array}$ & 41.26 & $\begin{array}{r}183 \\
53.84 \\
\end{array}$ & $\begin{array}{r}5 \\
45.5 x^{2}\end{array}$ & $37.5 \%^{3}$ & $\begin{array}{r}175 \\
50.44\end{array}$ & $\begin{array}{r}10 \\
66.7 \%\end{array}$ & $37.5 \%$ & $\begin{array}{r}194 \\
57.44\end{array}$ & $\begin{array}{r}15 \\
60.00\end{array}$ & $\begin{array}{r}6 \\
54.5 \%^{6}\end{array}$ & $46^{1}$ \\
\hline Sounk<0 & 796 & 3 & $\begin{array}{r}60.0 \% \\
8\end{array}$ & 154 & 3 & 10 & 141 & 6 & 4 & 157 & 4 & 5 & 132 & 9 & & 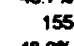 \\
\hline $\begin{array}{l}\text { Summation } \\
\text { x of total days }\end{array}$ & $\begin{array}{r}44.3 \% \\
121.24\end{array}$ & $60.0 \%$ & $40.0 \%$ & 47.4\% & $37.5 \%$ & $58.8 \%$ & 41.5\% & 54.5\% & $50.0 \%$ & $45.2 \times$ & $26.7 \%$ & $62.5 \%$ & & $36.0 x$ & $45.5 \%$ & \\
\hline 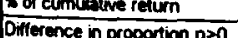 & & & & & & & & 05 & 10.13 & & 0.09 & & & 0.1 & 0.08 & \\
\hline $\begin{array}{l}\text { lifterence in proportion p } \\
\text { p pooled }\end{array}$ & & $\begin{array}{r}(0.08) \\
0.48\end{array}$ & $\begin{array}{l}0.12 \\
0.49\end{array}$ & & 0.54 & 0.53 & & 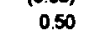 & 0 & & & 0. & & & 0.47 & \\
\hline$s_{1+2}$ & & 0.50 & 0.16 & & 0.25 & $0.2 t$ & & $0 .<=$ & 0.36 & & 0.17 & 0 & & 0.14 & 0.23 & \\
\hline $196(s)=$ & & 0.98 & 0.31 & & 0.49 & 0.41 & & 0.50 & 0.70 & & 0.33 & 0.00 & & 0.27 & 0.44 & \\
\hline & & $Y$ & צ & & & $\gamma$ & & $\gamma$ & & & & $Y$ & & & & \\
\hline $\begin{array}{l}\text { Difiterence in variance } \\
s_{1}^{2} / s_{2}^{2}\end{array}$ & & & & & 28019 & 6186 & & 1.6005 & 2.6270 & & 0.4849 & 1.4096 & & 0.5050 & 0.6979 & \\
\hline$=000$ & & 2.607 & 1.772 & & 2.328 & 1.843 & & 2.086 & 2.325 & & 1.905 & 2.325 & & 1.685 & 2.009 & \\
\hline Eneure $s_{1}^{2} / s_{2}^{2}>1$ & & 1.7015 & 1.3800 & & 2.8019 & 1.6186 & & 1.0005 & 2.6270 & & 2.0622 & 1.4096 & & 1.9802 & 1.4328 & \\
\hline av & & Y & 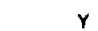 & & $\mathbf{N}$ & $\gamma$ & & & $\mathbf{N}$ & & $\mathbf{N}$ & Y & & $\mathbf{N}$ & & \\
\hline Significance levet & & $\%$ & $6.8 \%$ & & $1.5 \%$ & 13.78 & & $15.9 \%$ & $2.4 \times$ & & $2.7 \%$ & $34.0 \%$ & & $0.9 \%$ & $32.9 \%$ & \\
\hline
\end{tabular}

